\title{
7 Perceived safety in Swedish rural areas
}

People fear crime less in rural areas than they do in urban areas. It is submitted that this fact represents a partial picture of perceived safety, because people can fear greatly even if they perceive a slim likelihood of crime actually occurring. In this chapter, instead of reducing the issue of perceived safety to risk of victimization, the discussion is placed in a broader context with particular attention to rural areas in Sweden. As previously stated, "perceived safety" is a general concept used in this book to characterize both fear of crime and other overall anxieties captured by different indicators of fear and anxiety. The chapter looks beyond actual statistics of perceived safety between rural and urban areas in order to shed light on the nature of fear among people living in rural areas. The chapter includes critical analysis of two examples of expression of fear in relation to the process of othering in the Swedish country side: Sami youth (the old other), followed by the berry pickers (the new other). In order to illustrate in more detail patterns of perceived safety, two non-metropolitan municipalities: Jönköping and Söderköping are discussed in this chapter. The chapter closes with suggestions for possible further research on fear of crime in rural contexts.

\section{Rural perceptions of safety and fear of crime}

Traditionally, fear of crime is an urban phenomenon and is claimed to be a function of community size: greater fear in larger towns and cities, less fear in smaller towns and rural areas (Carcach, 2000; Ceccato \& Dolmén, 2013; Christie, Andenaes, \& Skirkbeckk, 1965; Hough, 1995). Higher rates of victimization in large cities are likely the core explanation of lower perceptions of safety (BRÅ, 2011; Donnermeyer \& Kreps, 1986; Skogan, 1990). However, looking more closely at this pattern, it is patchier than expected, heterogeneous across space and time and among groups.

Chapter 6 reviews a vast number of studies indicating that measures of fear of crime often capture other worries and anxieties than fear of crime itself. One reason is that both rural and urban areas are in constant change and in some cases converging, as new lifestyles are imposed by commuting patterns and wider access to ICT, for instance. Some of these changes imply new risks to individuals, producing new dynamics of fear and anxiety. Researchers have speculated that differences in 
declared perceived safety in certain rural and urban areas may not be that great (e.g., Ceccato \& Dolmén, 2013; Lawtley \& Deane, 2000; Pain, 2000).

In Sweden, if two individuals, one residing in Stockholm, the capital city, and another in the most remote area of the country, chosen at random are asked whether they have felt worry during the preceding 12 months, the chance of selecting an individual who declares feelings of worry is surprisingly similar in both places (Figure 7.1a). The same can be said about those who worry about their family's finances (Figure 7.1b).

However, where one lives seems to shape one's worry about crime. This is confirmed by different sources: Living conditions survey and Crime victims survey (Figure 7.1c and 7.1d). The chances of selecting an individual who will declare that he/she avoids going out in his/her own neighborhood because of a

(a)

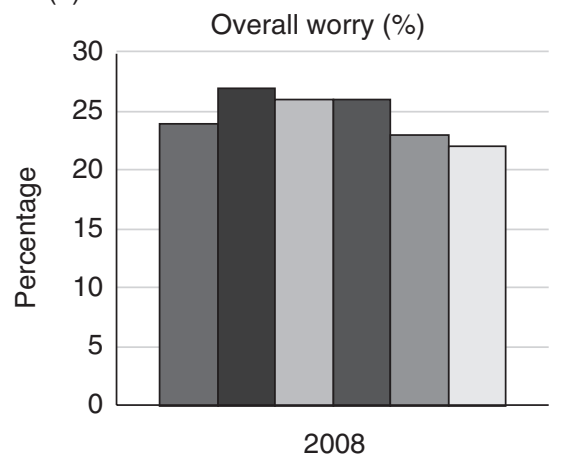

(c) Fear of being a victim of violent crime outside the home (\%)

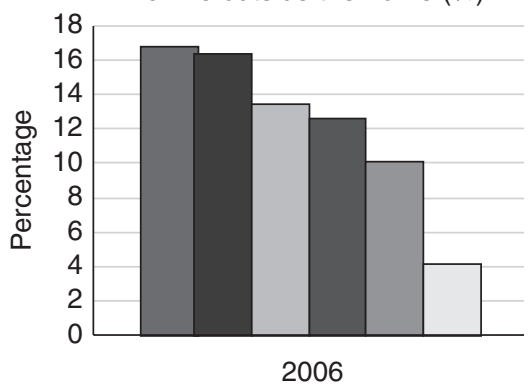

口Stockholm

- Göteborg/Malmö

口Larger cities

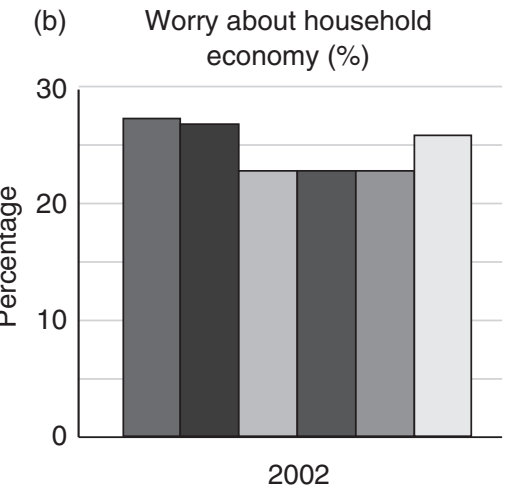

(d) Fear of being a victim of violent

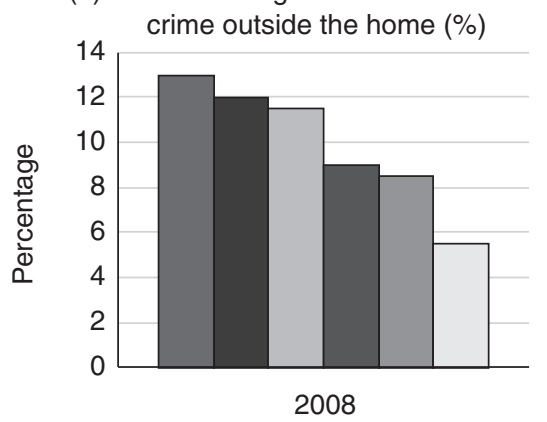

- South rural areas

$\square$ North accessible rural

$\square$ North remote rural

Figure 7.1 Indicators of overall worry/fear of crime in Sweden (data sources: (a) Living conditions survey, Statistics Sweden; (b) Victimization survey, Swedish National Council for Crime Prevention; (c) Living conditions survey, Statistics Sweden; (d) Victimization survey, Swedish National Council for Crime Prevention). 
fear of becoming a victim of crime is at least four times greater in Stockholm than in most remote rural areas of Sweden.

Why does overall anxiety not vary widely across the country though fear of becoming a victim of crime does? This mismatch between overall fear and fear of crime flags a number of unanswered questions.

1 Does perceived safety go beyond a deterministic link between fear and victimization?

In the Swedish case, overall worry seems to encompass more than a declared fear of crime as the pattern is quite uniform across the country (Figures 7.1a and 7.1b) and shows notably marginal differences between metropolitan and rural areas.

This pattern is not unique for Sweden. It reflects "a condensation of broader concerns about crime, stability and social change" (Gray, Jackson, \& Farrall, 2008, p. 377) found in many other studies elsewhere. For instance, Furstenberg (1971) has long suggested that these constructs were not significantly related to each other, that overall worry was more often associated with resentment and attitudes to social change that a place might be undergoing.

Interestingly, rural Sweden has become more criminogenic now than it was 10 years ago, and although crime rates remain lower in rural areas, the gap has narrowed slightly: accessible rural areas are nowadays in many respects similar to urban areas when police records are compared (Ceccato and Dolmén 2011). Yet, declared overall worry is similar in remote rural areas and metropolitan areas. Social changes are expected to affect lifestyles through access to information technology that creates opportunities as well as new risks. Moreover, the homogeneous pattern of declared overall worry may also be related to the fact that asking individuals about overall worry leads them to represent future-oriented anxiety rather than a summary of past episodes or current feelings of fear, as suggested by previous research (Sacco, 2005; Warr, 2000). The mechanisms that are at work in this case are, however, not clear.

2 Do patterns of declared overall anxiety follow the ecology of household/ family financial insecurity?

At first sight, Figures 7.1a and 7.1b are similar, which reinforces the idea that the ecology of overall worry has to do with patterns of individuals' concerns about their finances and perhaps future employment. Still, this is speculative as this potential link is based on an aggregated cross-sectional data set. The data does not provide hints about individual mechanisms linking current economic conditions and worry. For instance, concerns about one's health could also be part of the declared "overall fear" (Figure 7.1a).

Even more interesting, there is no significant difference between individuals living in the most remote rural areas in Sweden and individuals in the Swedish metropolitan areas with regards to worry about their household finances (Figure 7.1b). One possible explanation for this could be that overall fear is fed to a large extent by fear of crime in large cities, while in 
rural areas overall fear is mostly determined by concerns about individuals' and households' economic conditions - but both are expressed as "overall worry" as shown in Figure 7.1a. An alternative interpretation is that overall worry in large cities is composed of a mix of concerns but mostly expressed as fear of crime, as that is widely seen as a significant "social problem" (Gray et al., 2008, p. 377) shared by all people who live in big cities. In rural areas, overall worry is rather a result of unstable and limited employment opportunities and thus the vulnerability of the household economy.

Inequality in victimization may also explain this pattern. The poor are victims of crime more often and reveal more anxieties than wealthier groups in Sweden (Estrada, Nilsson, Jerre, \& Wikman, 2010). The poor are overrepresented in some large Swedish cities, such as Stockholm, Malmö, and Gothenburg, which would explain the urban-rural pattern in fear of crime illustrated in Figures 7.1c and 7.1d. Educational level and ethnic background are also related to unequal victimization and thus fear. The 2013 Swedish Crime Survey (BRÅ, 2014b, p. 92) reports that people born in Sweden with both parents born abroad are somewhat more concerned that relatives will be victimized by crime ( 28 percent) than those with at least one native-born parent (23 percent) and those who are foreign-born respondents (24 percent). Respondents with secondary education or higher state that they are concerned about relatives more often than those with no more than lower secondary education. Altruist fear is at work when couples with children are more worried than corresponding groups without children. In addition people living in rural areas are less worried about their family becoming victims of crime than those living in larger cities and metropolitan areas.

All the same, we cannot discard the possibility that overall worry is homogeneously distributed over the country, because that may reflect the a-spatial dynamics of victimization, such as through cybercrime. As suggested in Chapter 6, imposed daily commuting patterns from rural areas to larger cities may also dilute the sources of worry, as fear can be affected by the environments to which people are exposed.

3 Do patterns of declared fear of crime follow the hierarchy of the urban structure?

The answer is certainly affirmative to this question if Figures $7.1 \mathrm{c}$ and $7.1 \mathrm{~d}$ are taken as reference. Also, the 2013 Swedish Crime Survey (BR $\AA$, 2014b) reveals differences in insecurity among respondents living in metropolitan regions (17 percent), those living in other major cities (14 percent), and people residing in small towns or rural areas (11 percent). Moreover, respondents from metropolitan regions indicate that fear has a greater impact on their behavior and quality of life than residents of other rural areas. The pattern is largely the same as in previous years.

Previous research indicates that high crime rates promote fear (Skogan, 1990) but that the physical and social environment affects levels of fear of crime (Wilson \& Kelling, 1982). Thus, it is not a surprise that respondents living in apartments believe that fear has a greater influence on their behavior 
and quality of life than those living in single-family homes (BRA, 2014b). Urban areas provide a number of settings that trigger fear, some of which are crime attractors or generators (Brantingham \& Brantingham, 1995; Ceccato, 2013; Ceccato \& Hanson, 2013). Moreover, larger urban areas concentrate signs of physical deterioration, which is thought to be a more important determinant of fear of crime than actual crime is (Lewis \& Maxfield, 1980). As previously stated in Chapter 6, social interactions that take place at certain places may also lead to lack of perceived safety. Rural residents moving to large urban centers, for instance, may feel unsafe because the environment offers anonymity that may initially be perceived as a threat. Lack of familiarity, assistance, and protection (Hofferth \& Iceland, 1998; Milgram, 1974) may trigger fear. In urban settings, fear of the unknown or of others (Sandercock, 2005) can, more often than in rural areas, take various forms including a declared fear of crime.

Alternatively, urban areas concentrate groups of individuals who may be more fearful because of the conditions they are exposed to and, consequently, the risks they suffer (Box, Hale, \& Andrews, 1988; Jackson \& Gray, 2010). If there is an unequal risk of victimization (Estrada et al., 2010), and people who live in big cities are more at risk, then it is not surprising that people in big cities declare being more fearful about crime than those living in smaller and rural areas. This calls for a more detailed analysis of patterns of perceived safety by area and group. The next section explores some of these unanswered issues.

\section{The experience of crime according to Swedish National Crime Surveys}

In Sweden, the National Crime Surveys have been conducted since 2006 and have shown an overall stable victimization structure. The proportion of people who are very concerned about crime in the community has decreased, from 29 percent in 2006, to 19 percent in 2013. From 2006 to 2013, the tendency is clear: large cities - particularly those in the metropolitan counties of Stockholm, Skåne, and Västra Götaland - have a higher proportion of victims, more respondents declare feeling unsafe (for themselves or for their families), and more respondents have less confidence in the criminal justice system than respondents in the country as a whole. For 2013, the Swedish Crime Survey reports that respondents in metropolitan regions indicate vulnerability as victims of crime to a greater extent (4.9 percent) than those living in smaller cities or rural areas (3.6-3.9 percent).

More interestingly, the proportion of respondents living in Stockholm County who are concerned about crime has fallen steadily, from 30 percent in 2006 , to 17 percent in 2013, while in the southern county of Skåne, the share of those worried about crime has remained relatively stable since the mid-2000s. These southern parts of the country also show a higher proportion of respondents who agree that fear affects their quality of life (BRA, 2014a). 
Figure 7.2 illustrates differences in perceived safety by type of municipality. Figure 7.2 matches at first glance the patterns shown in Figures 7.1c and 7.1d. As expected, fear tends to be higher in urban areas $\left(\chi^{2}=57.1, \mathrm{df}=4, p<0.00\right)$ (Figure 7.2), where most people are victimized $\left(\chi^{2}=40.9, \mathrm{df}=2, p<0.00\right)$, often younger people (16-24 years old). Half of the respondents to the Swedish Crime Victim Survey (2007-2008) living in urban municipalities declare being more fearful in their own neighborhood than those living in rural and accessible rural areas (the relationship is significant: $\chi^{2}(4)=79.63, p<0.00$ ). However, some patterns in Figure 7.2 suggest a number of interesting possibilities.

1 Although measures of fear of crime and declared unsafety in the neighborhood are on the decline, the proportion of respondents avoiding going out because of fear is fairly constant over time (Figure 7.2a). This is an indication that there is always a group that is going to declare themselves to be more fearful and that the fear will affect their mobility patterns and quality of life regardless of their overall risk and society's perceptions. This group is composed of those who are less mobile and feel more vulnerable if victimized (the elderly, the disabled).

2 The graphs illustrating fear of crime and avoiding going out because of fear indicate that respondents living in large cities and towns declare slightly higher levels of fear than those in metropolitan areas (Stockholm, Gothenburg, and Malmö). A possible explanation for this is that cities and large towns have become more criminogenic than urban neighborhoods in the metropolitan areas in recent decades (Ceccato \& Dolmén, 2011). Another possible explanation is that whilst most fear measures are declining, the proportion of respondents declaring fear of residential burglary has been fairly constant since 2006 (Figure 7.2b), perhaps a reflection of the percentage of households reporting burglary ( 0.9 percent of vulnerable households in the country) and police statistics for burglary (see for instance, BRÅ, 2014b, pp. 58-59). Some of these municipalities have had population inflows (at least temporarily) which can affect crime risk and perceived safety of residents.

3 Fear of becoming a victim of a car-related theft has decreased since 2006 for all types of municipality. The proportion of households reporting having been exposed to car-related theft has declined, from 0.9 percent in 2006, to 0.4 percent in 2012. A significant reduction can also be observed in the registerbased statistics of reported car thefts during the same period: from approximately 27,000, to 12,000 between 2006 and 2012 (BR $\AA$, 2014b). According to Ceccato and Dolmén (2011), technologies implemented in new cars after the mid-1990s make these vehicles more difficult targets to steal from or to be stolen (e.g., use of immobilizers). People are reporting fewer car-related thefts also because insurance companies have increased their deductible amounts. If the value of stolen goods does not exceed the minimum value at which reimbursement can be claimed, there is a strong chance that a victim of crime will not bother to report the offense to the police. Finally, there may have been a displacement from more traditional types of crimes (such as car thefts), to 


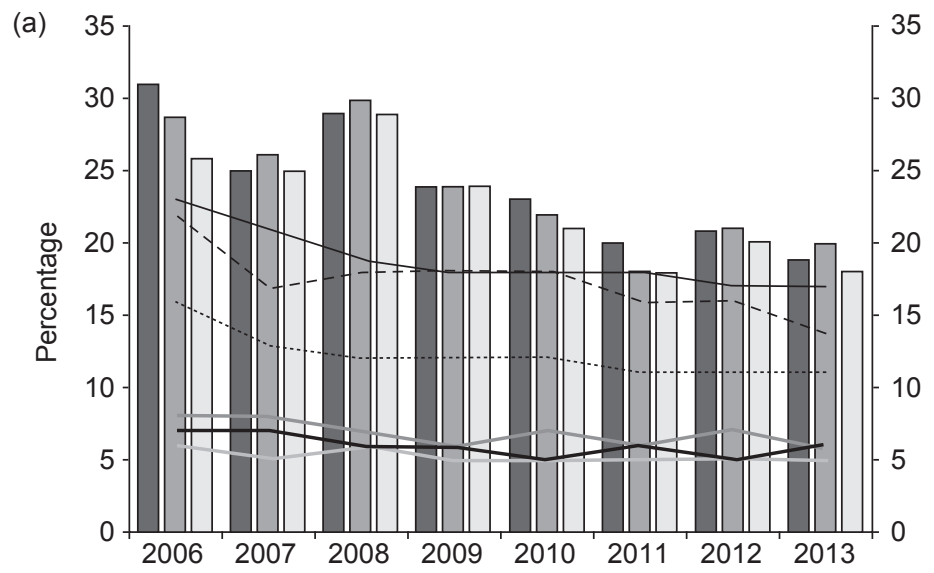

\begin{tabular}{lll} 
Fear of crime & \multicolumn{1}{c}{ Unsafe in neighborhood } & Avoid going out \\
$\square$ Metropolitan areas & - Metropolitan area & - Metropolitan area \\
$\square$ Large cities & -- Large cities & - Large cities \\
$\square$ Towns and rural areas & .... Towns and rural areas & - Towns and rural areas
\end{tabular}

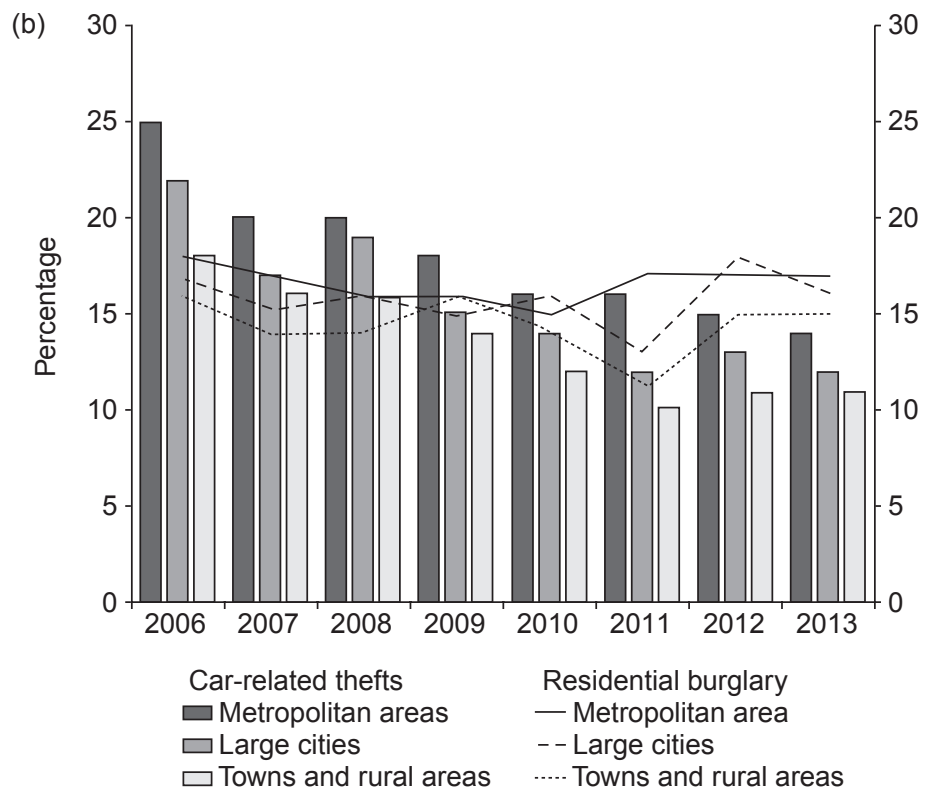

Figure 7.2 (a) Percentage of respondents on perceived safety by type of municipality and (b) fear of being victimized, car-related thefts, and residential burglary (\%) (data source: BRA, 2014b, pp. 106, 108, 110). 
other types of offense, such as fraud. Still, this explains lower reporting rates but not exactly lower declared fear levels for car-theft victimization.

Respondents living in small towns or rural areas worry that they will become the victim of assault to a lesser degree than residents of urban areas do ( 7 percent and 10-13 percent, respectively). The differences in concern about crime between urban and rural areas mainly relate to assault and burglary when the effects of other factors such as age, gender, family, and type of housing are controlled for.

Note that figures from the Swedish Crime Victim Survey show that overall worry does differ in remote rural and urban areas (Figure 7.2) - a difference not much pronounced in Figure 7.1a, based on a national living conditions survey. Even greater differences are apparent between urban and remote rural areas concerning the fear of being a victim of crime in the neighborhood, as previously noted. Methodological differences and types of aggregation could also explain differences in the patterns seen in Figure 7.1a and Figure 7.2.

The proportion of those feeling unsafe walking alone after dark in the neighborhood is close to 7 percent of respondents in accessible rural areas and 2 percent in remote rural, compared to 12 percent in urban areas. Similar figures are found by the British Crime Survey, reported by Marshall and Johnson (2005), namely 8 percent for rural areas and 13 percent for urban areas (for the inner city in urban areas, one-quarter of respondents declare feeling unsafe).

Following the findings of international research on fear, gender, and victimization (see Chapter 6), in Sweden previous victimization (of oneself or a family member) strongly correlates with declared fear, different measures of fear, and the experience of witnessing violence (BR $\AA, 2014 \mathrm{~b}$ ). Unequal victimization and fear appear when only rural areas are assessed. In rural areas, a strong correlation was found between those who were victimized (or someone from the family was victimized or witnessed violence) and those who feel unsafe where they live or often avoid activities outdoors because of fear of being victimized (around $r=0.90-0.97$ significant at 0.01 level, based on data for 2006-2008). Females tend to be more fearful than men regardless of where they live, but those living in urban areas in the south declare themselves to be more fearful than those living elsewhere in the country.

Corroborating the hypothesis of fear and social change, the Swedish data shows that half of respondents living in urban municipalities or in accessible rural areas that have had a positive population increase state more frequent worries about crime than those living in rural municipalities (The relationship is significant: $\chi^{2}(4)=71.86, p<0.00$.)

\section{Fear of crime and the perceived seriousness of offenses}

Fear induced by different crimes depends not only on the perceived risk but also on the perceived seriousness. In reality, the relationship between the seriousness of crime and fear is not well understood. Homicide ranked low on the list of fears, 
while residential burglary outranked all other offenses. To generate strong fear, Warr (2000, p. 458) suggests, an offense must be perceived as both serious and likely to occur. The author exemplifies by reporting empirical evidence from Seattle, WA. Residential burglary is the most feared crime in the United States because it is viewed as both relatively serious and rather likely. Murder, on the other hand, is perceived to be very serious but unlikely to occur (for a review, see Warr, 2000).

In Sweden, similar trends are found for property and violent crimes, at least in the 2013 National Crime Survey. For violence, the proportion anxious about becoming a victim of assault decreased, from 15 percent in 2006, to 10 percent in 2013, while for residential burglary the fear levels remained relatively stable throughout the survey period, around 16 percent. Perceptions of crime seem also to follow crime trends. The rate of exposure to residential burglary has remained relatively unchanged since 2006 , while the proportion who stated that they had been the victim of assault declined gradually, from 2.7 percent in 2006, to 1.9 percent in 2012 (BRÅ, 2014c).

In the United Kingdom, there seems to be little difference between the proportion of those worried about becoming the victim of violence or theft. For instance, in the mid-2000s 15 percent of respondents declared they were worried about becoming a victim of either physical attack or residential burglary if they lived in urban areas. However, if they lived in rural areas, about 10 percent of respondents declared they were worried about becoming a victim of assault or property crime (Marshall \& Johnson, 2005). In the 2010/2011 British Crime Survey, 10 percent of adults were worried about burglary and car crime, and 13 percent of adults were worried about violent crime - a measure for the whole country. These proportions were the lowest recorded since the questions were introduced in the 1990s (Chaplin, Flatley, \& Smith, 2011).

\section{Safety from the perspective of farmers, the elderly, and minorities}

\section{Victimization and perceived safety among Swedish farmers}

As much as 57 percent of farmers in Sweden feel at least a bit worried about becoming a victim of crime and 25 percent are worried about the future (Figure 7.3), according to the Farmers' Safety Survey (Lantbrukarnas Riksförbund, 2012).

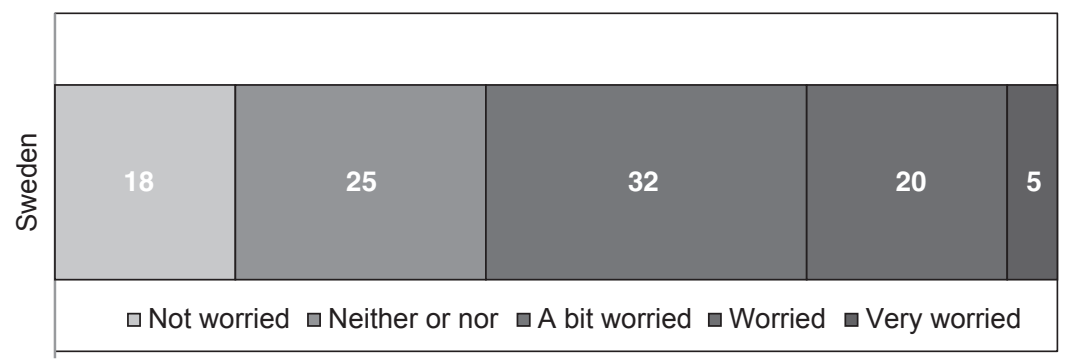

Figure 7.3 Do you worry that you and/or your farm will be victimized? (\%) (data source: Farmers' Safety Survey $(N=527), 2012)$. 
2012). Although only three out of 10 farmers have been victims of crime in the past two years, seven out of 10 farmers know at least one other person who has been victimized. SAS is a postal questionnaire sent to 1,000 farmers who operate agricultural properties with more than 10 hectares of field. In 2012, the survey had a 62 percent response rate, considered enough to represent the group.

Victimization is more concentrated in the south than the rest of the country. In southern Sweden, the proportion is larger (eight out of 10), especially among those respondents who own farms with more than 50 hectares (they are often more victimized than the rest). Thefts tend to dominate the victimization statistics for farmers. Thefts of fuel and building equipment are common, but also fraud by telephone and Internet as well as payment of false invoices. Farmers are also victims of theft of livestock, burglary in the house or other farm property, as well as vandalism (residential, on the property, and on roads). Half of those who have been victims of crime were targeted two or more times. There is a clear lack of confidence in local police forces to solve these crimes. One in four respondents had had a case dismissed by the police. The same proportion of farmers was worried that their properties or their family would be victimized in the future. Those in northern Sweden feel less anxious than the national average about the prospect of being victimized by crime, whether themselves, their family, or their property. Chapter 8 discusses victimization and perceived safety among farmers in more detail.

\section{Victimization, fear, and the elderly}

In Sweden, approximately 19 percent of the current population is older than 65 years of age, and by 2020 one-quarter of the population will be older than 65 (Schyllander \& Rosenberg, 2010). A substantial portion of the elderly live in smaller urban and rural areas, and the proportion of the elderly living in rural and many smaller urban areas in much of the country is higher than the national average (Karlsson, 2012). Those who want to have some degree of independence are vulnerable to the way indoor and outdoor environment is built. Although many elderly are afraid to go out because of possibly becoming a victim of crime, they run a low risk of victimization. The biggest threat to their safety is the risk of falling. The most dominant cause of elderly people falling in Sweden is slipping, tripping, and stumbling, often at home or nearby - and not crime (Bamzar \& Ceccato, 2015). There is reason to believe that the fear of being outdoors declared by many elderly people reflects other types of risk (e.g., fear of falling) rather than the risk of becoming a victim of crime.

Nationwide, victimization among the elderly is relatively low. The Swedish Crime Survey shows that elderly victimization through assault, threats, sexual offenses, robberies, fraud, and harassment has decreased during the past five years, from 7 to 4.4 percent. For the oldest group, 75-79 years old, victimization varied between 3.7 and 4.7 percent. The most common type of crime against the elderly is theft, usually theft from the residence without a break-in. The results 
of the national public health survey also show that older people declare being victims of physical violence, threats, and other types of violence. In contrast, three of every four women in all age groups declare that they refrain from going out alone for fear of being attacked or robbed. There are probably many unreported cases of domestic violence (Torstensson, Forslund, \& Tegnell, 2011). In 2013 , the lowest percentage of victimization was in the age groups 65-74 years ( 0.3 percent) and 75-79 years ( 0.2 percent). As expected, the low risk of victimization does not translate into high perceived safety. According to BRÅ (2014b), it is mainly older people who say they feel unsafe outdoors. From 2006 to 2013, women aged 75-79 years were the group that felt least safe late at night outdoors, especially those living in urban areas (26 percent, compared to 19 percent in the youngest group).

In Jönköping, the town used as an example in this chapter, elderly people do not express themselves as fearful beings, quite the opposite. Contrary to what is commonly found in the international literature, in Jönköping the elderly (65 years and older) are not necessarily more anxious about their safety than other respondents. They feel safer in relation to their risk of being victimized $\left(\chi^{2}(2\right.$, $N=454)=13.0, p=0.00)$ and have not been victimized in the 12 months preceding the survey $\left(\chi^{2}(2, N=452)=3.38, p=0.06\right)$. Together with mothers on maternity leave and part-time employees, they show indications of having better knowledge about what happens in the area. This group is more sensitive to littering and vandalism $\left(\chi^{2}(2, N=433)=3.60, p=0.06\right)$ and more critical about the adequacy of the outdoor environment for young people $\left(\chi^{2}(2, N=453)=6.57\right.$, $p=0.01)$ than other groups of respondents are. The elderly also seem to be less suspicious about people $\left(\chi^{2}(2, N=455)=9.81, p=0.00\right)$ and think they can trust them more than other respondents do $\left(\chi^{2}(2, N=455)=3.57, p=0.06\right)$. Previous studies in urban areas highlighted the proportion of elderly as an indication of strong social control. For instance, drawing on the work of Felson and Cohen (1980), LaGrange (1999) points out that residents are likely to be absent from their homes more frequently, so guardianship may be substantially reduced. Spending time in the area improves individuals' knowledge of it, making them feel safer. This is true for the elderly and people with no full-time job.

\section{Ethnic minorities and expressions of fear}

Feeling unsafe is more common for foreign-born individuals than for those who were born in Sweden (23 percent and 13 percent). In addition foreign-born individuals are more likely to declare that low perceived safety affects their quality of life than are people born in Sweden (14 and 8 percent, respectively). Lower perceived safety among ethnic minorities is linked to greater victimization. According to BR $\AA$ (2014b), foreign-born individuals (2.7 percent) are victims of assault more often than residents with two parents born abroad (2.2 percent) or one parent born abroad (1.7 percent). There are no significant differences in exposure to violence based on where one lives (urban or rural areas), except for serious assault. People living in big cities experience a slightly higher exposure to serious assault (0.6 
percent) than those living in other major cities, small towns, or rural areas $(0.3-0.4$ percent). Foreign-born individuals are also over-represented among victims of threat, robbery, and fraud, particularly those with a secondary education. For harassment, foreign-born individuals living in urban areas state that their vulnerability to harassment is slightly higher than people living in large cities or in rural areas.

At a local level, the pattern is the same. In Jönköping, for example, residents born outside the Nordic countries tend to be overrepresented among those who fear most their neighborhood $\left.\left(\chi^{2}(2, N=445)=3.78, p=0.05\right)\right)$. A total of 11 percent of respondents feel that there are people in their neighborhood who are threatening, and 10 percent of respondents feel fear due to their ethnic affinity, either Swedish or non-Swedish. Ceccato and Wilhelmsson (2014) also show that the perception of discrimination where one lives has a direct effect on how attractive an area is valued in the housing market.

\section{Minorities and discrimination: fear of the other in rural areas}

This section takes two Swedish examples to illustrate fear of others, considering the issue through the eyes of those who have a contradictory position: sometimes viewed as suffering a number of anxieties themselves for not being the norm, and sometimes as being the source of the local fears. Two groups were selected: young Sami people living in northern areas of Sweden who have historically suffered discrimination (the old others), and berry pickers who come temporarily to Sweden in the summer to work (the new others). The Sami and berry pickers were also chosen because they contrast with the current representations of Swedish modernity. The nomadic Sami culture or underdeveloped berry picker industry survive in parallel and contrast with, as indicated by Pred (2000), the Swedish market image of a progressive, liberal, and modern society free from racism, sexism, and other inequalities.

\section{The Sami youth}

Fear is an expression of the exclusion long experienced by young Sami. Sami are the indigenous people (an estimated 40,000 inhabitants) of Sweden who have a long history of discrimination, racism, and conflict that, according to Omma (2013), has had a significant impact on Sami self-esteem and on their health, especially mental health. They are not a homogeneous group and, in Sweden, they are geographically spread from central Sweden to the north. Sami in Sweden are traditionally engaged in reindeer husbandry, woodworking, hunting, and fishing (Skielta, 2014). As Omma (2013) reports, poor health is one of the symptoms expressed by this group of young people. She shows that unfair treatment because of their ethnic background was declared to be frequent among young adult Sami (about half of all respondents reported this experience, and 70 percent of reindeer herders).

Young people continually develop their own understandings of their culture in order to interpret their own lives. Omma (2013) suggests that feeling safe is 
fundamental to developing a sense of feeling at home for the Sami. The author reports that a majority of young adult Sami have declared themselves proud to be Sami and expressed a wish to preserve their culture. However, the lack of knowledge in mainstream society makes the Sami feels they must constantly explain and defend the Sami way of life. Both young adult Sami and a reference group of young Swedes from the same geographical area reported having suicidal thoughts to a high degree, but it was more common among Sami. Sami reindeer herders and those poorly treated because of their ethnicity reported a higher degree of suicide attempts compared to Sami without this experience (Omma, 2013).

Discrimination against old minorities in rural contexts is not an exclusively Swedish phenomenon, of course, but is well documented in Australia (e.g., Babacan, 2012; Cunneen, 2007; Forrest \& Dunn, 2013; Scott et al., 2012), Canada (Jain, Singh, \& Agocs, 2000), and the United States (Hartshorn, Whitbeck, \& Hoyt, 2012), to name a few. Young people in these groups are often unable to participate as equals and benefit from the opportunities available to other citizens. In Swedish society, this gives rise to long-term anxieties that hamper young people's opportunities in life. For society as a whole, these findings have a number of implications. One is that the denial of racism can send a message that racist behavior is allowed and not punished. Another implication is that the situation requires in-depth knowledge about minorities in rural contexts, their right to full citizenship, and the construction of fear.

\section{Temporary summer workers: berry pickers}

Every summer, the Swedish media is populated by articles reporting travelers' whereabouts and temporary workers in rural areas. Most report the work and living conditions of this temporary labor force. Fear and feelings of insecurity characterize accounts of conflicts between the temporary workers and locals.

In times of intense mobility (Urry, 2002), the movement of temporary labor in European countries is still regarded as problematic. An example of this is the case of berry pickers. This flow of low-wage labor is characterized by a number of fears, unsafe working conditions, and racism in a high-profit industry. Sweden and Finland are the largest bilberry exporters among the Nordic countries (Eriksson \& Tollefsen, 2013). Communities that host these temporary workers show cases of poor tolerance for nomadic labor. These workers are perceived with suspicion and fear. Since 2010, the number of work permits granted for berry pickers in Sweden has increased (Figure 7.4). After accusations of abusive working conditions emerged, rules for employing berry pickers were recently tightened (Axelsson, 2014), reducing their inflow in 2014.

The author also reports that all berry pickers came to Sweden voluntarily from Bulgaria and other Eastern European countries, as the previous years' good berry crop had fueled rumors that it was possible to make money on berries in Sweden. This specific case refers to the inflow of about 500 berry pickers in 2012, mainly from Bulgaria, into Mehedeby, a community in northern Sweden 


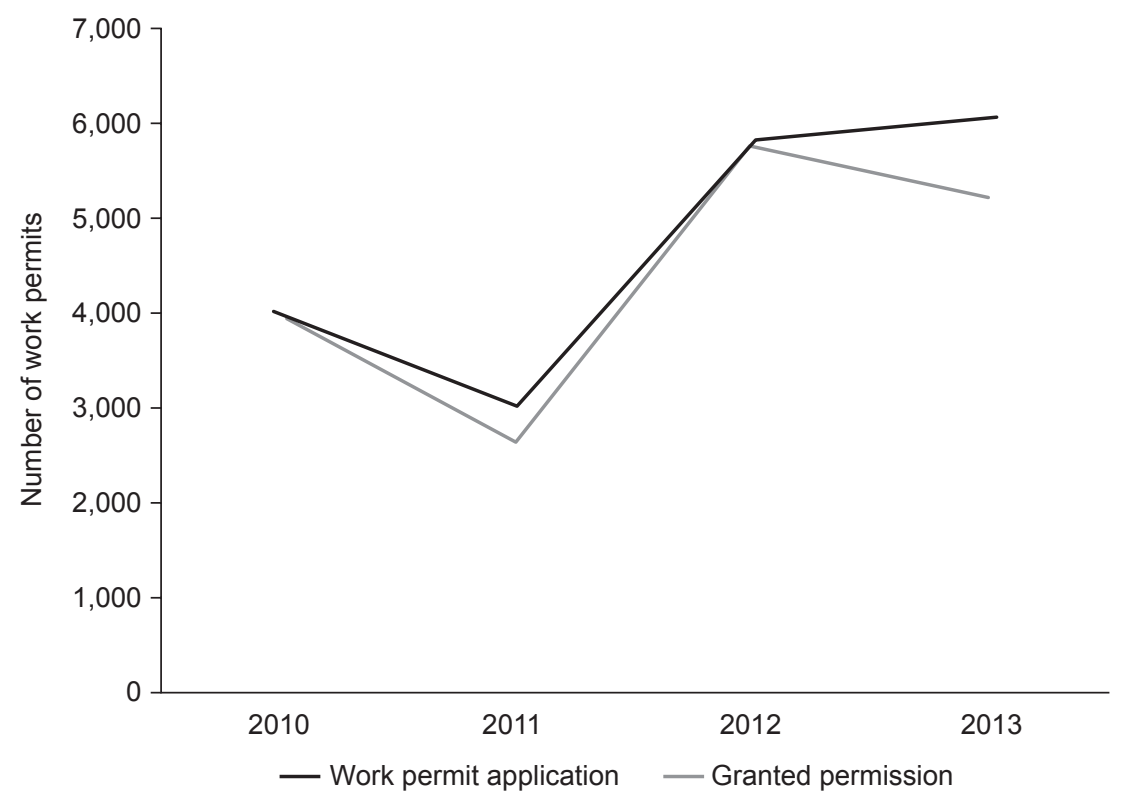

Figure 7.4 Work permits for berry pickers, 2010-2013 (source: Axelsson, 2014).

with 450 inhabitants, as reported by Leander (2012). The mood in the camp seemed friendly, but many workers wanted to talk about their living conditions, as they did not have access to drinking water or toilets. They had to collect water from a service station a few miles away. Still, a resident expressed concerns about the "incomers."

They must be removed. We cannot have 600-700 people here ... many thefts have been committed since they arrived here.... They go into the plots and look for food in the garbage.

(Leander, 2012)

Hollway and Jefferson (1997) indicate how the narrative of locals informs an order in which some behaviors are perceived as extreme threats to the social order and others are ignored or dismissed. This partial view is exemplified by the case above, where workers' living conditions are ignored in the discourse of the local resident.

Although nomadic populations and travelers have long been associated with crime and problems of social order in the media (e.g., Jansson, 2011), Halfacree (2011, p. 124) points out how these groups in the United Kingdom "are routinely constructed as a key public order problem (real or imagined)." As suggested by Scott et al. (2012), concerns are rarely a reflection of objective risk that the new 
impose, but are bound up in a wider context of meaning and significance, involving the use of metaphors and narratives about social change, as illustrated by the following narrative. In the Swedish case, Leander (2012) reports the mismatch between villagers' perceptions of incomers and actual signs of crime and disorder as indicated by the local police chief:

The fear among the residents (of the village) is great, but we have not seen any major increase in crime.

The case of berry pickers in Mehedeby exemplifies the challenges that rural communities face when receiving a large number of foreign temporary workers in the Swedish countryside. The police feel local pressure to keep an extra eye on the temporary workers living in the forests. Still, Halfacree (2011) notes that an important question is why this particular group of workers requires extra attention from residents, the police, and all other local actors involved in policing work. "Who are the offenders?" is also a relevant question, as alleged cases of slavery and human trafficking have been associated with this temporary labor force. The berry industry across Europe is pointed out by the media as failing to provide basic satisfactory conditions for work, particularly to those workers coming from outside the European Union: "The food industry today announces stricter demands on wholesalers to improve conditions for berry pickers. 'Control is inadequate,' according to the national coordinator against human trafficking in Sweden” (Fagerlind, 2013).

A better understanding of the role and the impact of these temporary workers on the rural community is necessary, hopefully associated with a more extensive debate on the need to improve their living and working conditions in the countryside up to the level that a modern society, such as Sweden, is expected to have.

\section{Perceived safety in the rural}

Using Chapter 6 as a reference, this section reports perceived safety through the eyes of those who live far from the metropolitan regions of Stockholm, Gothenburg, and Malmö. This section focuses primarily on an analysis of safety surveys of Jönköping. As much as possible, findings from Jönköping are compared with perceived safety in the town of Söderköping, $170 \mathrm{~km}$ away from Jönköping and $170 \mathrm{~km}$ away from Stockholm.

\section{The experience of crime according to the Jönköping crime survey}

Jönköping is located in central-southern Sweden, a three-hour drive from Stockholm $(320 \mathrm{~km})$. Jönköping has a population of about 130,000, which makes it Sweden's ninth largest city. The urban area is a result of the conurbation process of two localities: Jönköping and Huskvarna. The city unofficially has two "centers" around Lake Vättern: Jönköping to the west and Huskvarna to the east. Jönköping Municipality has shown a slight increase in total population, while several small towns in the same county have experienced a decrease (Länstyrelsen, 2012). The 


\section{2}

average net income for families in Jönköping is less than for the nation as a whole. So-called "vulnerable residential areas" are dominated by apartment buildings and a population with high unemployment and low education levels. In these areas, dependence on social allowance is high compared to the city as a whole. These areas often have a large proportion of foreign-born persons (Jönköping city office, 2009) and are located on the outskirts of the municipality.

It is no surprise that Jönköping is perceived by its inhabitants as a safe place. According to the 2013 victimization survey, ${ }^{1}$ a large majority feels safe at home and in the neighborhood where they live, more often in daytime ( 80 percent) than nighttime (78 percent). Among those who do not feel safe all the time, it is often in the dark hours of the day that they feel less safe (note that in winter in Stockholm, the hours of daylight may be as few as six hours a day while in north Sweden, the hours of daylight may be less than three hours a day). They are concerned about loved ones, family, and friends if they are out (16 percent). Some declare being suspicious about those they meet, or taking other roads than usual when they are out at these times, or avoiding going out during these times (7 percent). A similar pattern of perceived safety is found in Söderköping, a town smaller than Jönköping. There, 90 percent declare feeling safe or very safe (Lundin, 2006). ${ }^{2}$ Table 7.1 summarizes some of the key indicators of perceived safety in Jönköping and Söderköping.

In Jönköping as in Söderköping, the perception of safety is not evenly distributed across groups and space (Figure 7.5). On the maps in Figure 7.4, those who declare being fearful may run a slim risk of becoming a victim of crime, either violent crime or residential burglary (Figure 7.5a and 7.5b, respectively. Fear of being victimized by crime may be inversely correlated to average income in other Swedish cities (City of Stockholm, 2011), but in Jönköping the pattern is patchy (Figure 7.5c). Although personal victimization is a significant differentiator between those who are fearful and those who are not, such a relationship is difficult to identify for the whole sample $\left(\chi^{2}(2, N=454)=34.7, p=0.00\right)$ on the map (Figure 7.5d).

These findings of perceived safety in Jönköping do follow the patterns found in international studies (see Chapter 6). For instance, the group that tends to declare feeling more worried about places and people are those that have already been a victim of crime or are unemployed $\left(\chi^{2}(2, N=456)=7,63, p=0.01\right)$. Immigrants also tend to feel more vulnerable to crime as victims than native

Table 7.1 Victimization and safety in two Swedish towns

\begin{tabular}{lcl}
\hline In the last 12 months (\%) & Jönköping $N=462$ & Söderköping $N=300$ \\
\hline Victimization of crime & 6 & 15 (urban core) 8 outside \\
Feel safe (or very safe) & 80 & 90 \\
Avoid going out because of fear & 7 & 16 \\
Fear for others & 16 & 11 \\
\hline
\end{tabular}

Data sources: Ceccato and Wilhelmsson (2013): Lundin (2006). 


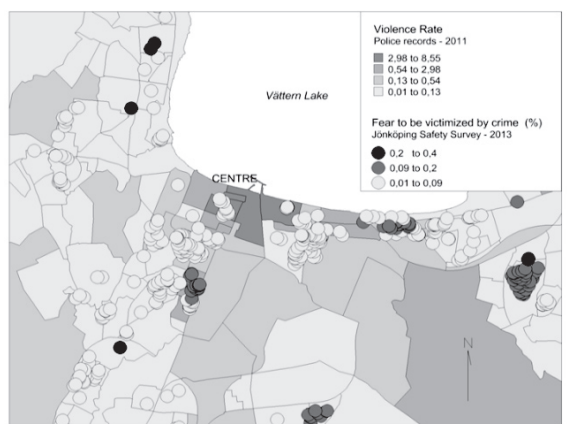

(a)

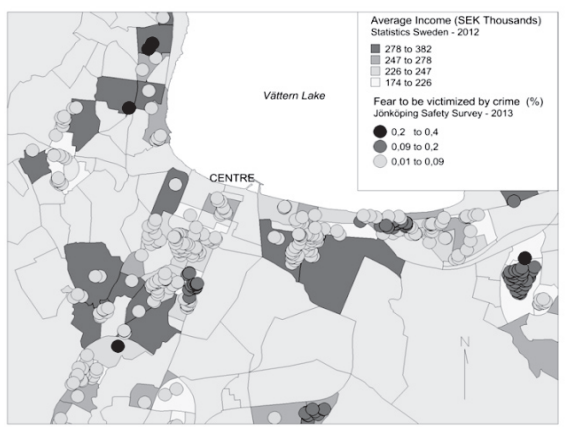

(c)

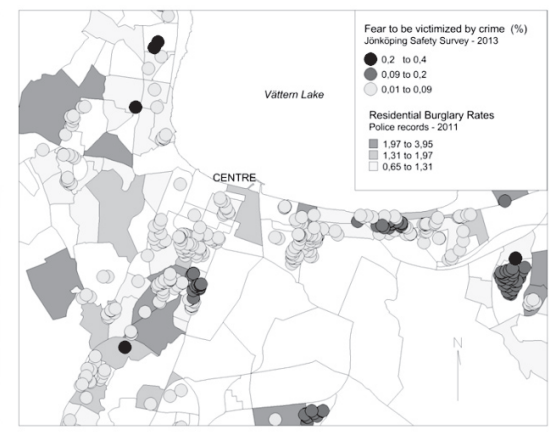

(b)

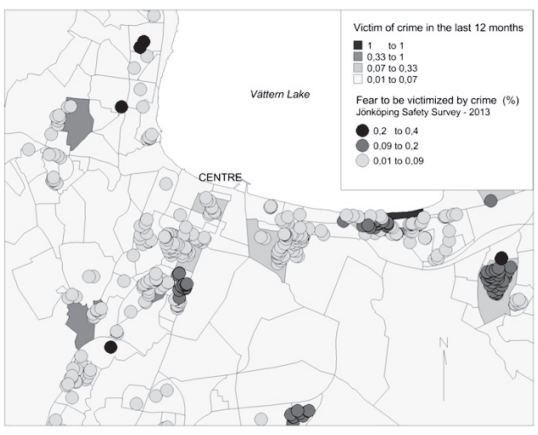

(d)

Figure 7.5 Fear of being victimized by crime in relation to rates of (a) violence, (b) residential burglary, (c) average income, and (d) personal victimization (data source: Jönköping Safety Survey, 2013).

inhabitants do $\left(\chi^{2}(2, N=444)=9.10, p=0.01\right)$. Interestingly, those who live alone are more fearful than those living in a household with two or more residents $\left(\chi^{2}(2, N=451)=3.51, p=0.06\right)$.

In Jönköping, no significant gender differences are apparent for declared fear, as was found in Söderköping (Lundin, 2006). However, in Jönköping women more often than men avoid going out at certain times of the day $\left(\chi^{2}(2, N=456)=6.01\right.$, $p=0.01)$. In Jönköping, women's avoidance behaviors do not seem to be triggered by the physical or social environment where they live (bad illumination, dark tunnels or forests, the neighborhood layout, people asking for money, drunkards/ drug addicts in public places, or disturbing neighbors). However, women are more sensitive to neighbors and other individuals, such as peepers (fönstertittare) $\left(\chi^{2}(2, N=436)=2.76, p=0.09\right)$. Still, women are used to chatting and exchanging favors with neighbors more often than men are (about two-thirds of women).

There are signs that altruistic fear is at work here, too. From those who declare worry (sometimes or often), one-quarter are concerned for themselves, their family, and friends. As suggested in Chapter 6, declared fear in the 
neighborhood is also triggered by the conditions of physical and social environment. Respondents complain about poor illumination (30 percent) and littering (26 percent). Half of respondents were able to indicate one or more places in their neighborhood that trigger "unsafety," such as tunnels, bus stops, parks, and parking lots. Signs of physical deterioration in these areas seem to indicate that something else is happening. For instance, these areas are also indicated as having problems with graffiti and vandalism (28 percent) and theft (16 percent). One participant in the survey highlights the need for both formal and informal social control in the area:

Burglary is not uncommon ... we need more police and to keep an eye on what happens here.

(Survey participant, 2013)

More interesting is that 45 percent of the interviewed population declares being a bit worried or worried about being victimized by crime in their own home, in their neighborhood, or in Jönköping as a whole, even if they have never been a victim of crime. Wilhelmsson and Ceccato (2015) indicate that the number of police-reported crimes per 1,000 inhabitants in Jönköping is lower than the national average. This applies to both violence and thefts, but since early 2000, rates of reported violence have increased faster than for the national as a whole (about 33 percent in Jönköping and 28 percent in Sweden). For theft, Jönköping follows the national trend of 30 percent reduction since 2000. In Söderköping, for instance, the perception of future victimization is similar to the one illustrated above for Jönköping. However, it depends on type of crime (40 percent for violence, 52 percent for residential burglary, 32 percent for theft, 23 percent for vandalism, and 18 percent for robbery).

Street violence and vandalism happen mostly in the inner-city areas, which impacts on people's perceived safety regardless of where they live. The center of Jönköping (50 percent) and, to a lesser extent, the center of Huskvarna (20 percent) were perceived as less safe than respondents' own neighborhoods, even when most respondents are familiar with central areas, going there at least twice a week. This fact corroborates the theory that inner-city areas, even in small towns such as Jönköping, have features that negatively affect the perceived safety of residents. The following two participants highlighted features of inner city areas that, according to them, decrease the safety of the area:

Our safety is compromised by what happens during the night. Close down the strip club. It's 50 meters from a secondary school and 20 meters from an elderly-care home!

(Survey participant, 2013)

They turn off the lights at 11:00 p.m. here. We need better illumination especially along pathways and in tunnels and parks. 
Residents declare they feel safer in places they are more familiar with and where they spend more time, except for inner city areas. For instance, most think their neighborhood is safer than any other neighborhood $\left(\chi^{2}(2, N=450)=7.53\right.$, $p=0.06$ ). However, 44 percent of respondents still feel some concern about becoming a victim of crime in their own dwelling or nearby places (bus stop, stairwell, basement, laundry room, convenience store).

The quality of the physical environment does contribute to poor perceived safety: 60 percent of respondents think that pedestrian tunnels are the most dangerous places, 55 percent think that Jönköping's downtown area is dangerous, while parks are selected by 30 percent of respondents, followed by bus stops, 22 percent. Better illumination is also associated with the quality of walking and cycling routes; 15 percent believe these places are unsafe.

Perhaps it is not only the time spent in one place that matters to safety but also what one does. Overall 65 percent believe that their neighborhood is safer than any other place in Jönköping when they know people locally $\left(\chi^{2}(2\right.$, $N=451)=16.7, p=0.00)$ ). Half of those who were interviewed rely on neighbors to keep an eye on their property when they are away. The criminology literature has long suggested the importance of social environment to safety. Bursik (1999) suggests that much focus has been put on the effect of "supervisory" capacity of communities to limit crime and contribute to safety. Yet within neighborhoods, the ability of residents to exchange favors and develop mutual trust differs, which results in variation in residents' perceived safety, according to Cancino (2005). Some respondents expressed willingness to act for the "common good" as a sign of the collective efficacy of the group (Sampson, Raudenbush, \& Earls, 1997), such as by working on neighborhood watch schemes. As expected, those who own their home $\left(\chi^{2}(2, N=449)=24.0, p=0.00\right)$ declare feeling safer than those who rent. Owners also believe that the environment they live in is good for their children $\left(\chi^{2}(2, N=459)=25.1, p=0.00\right)$, have often lived there for more than five years, and have established contacts with neighbors.

But not everybody feels safe "at home." Most of those who are fearful feel unsettled where they live now $\left.\left(\chi^{2}(2, N=458)=30.2, p=0.00\right)\right)$. According to Jönköping's safety survey, more than one-quarter of respondents are worried about crime, either for themselves or close family members, which makes them extra vigilant (9 percent), avoid going out at certain times ( 7 percent), choose taxis (6 percent), and avoid talking to people they do not know (5 percent). Foreign-born respondents are more fearful than natives where they live $\left(\chi^{2}(2, N=445)=3.78\right.$, $p=0.05)$ ). Some of these areas have a high proportion of rental units. As previously suggested, these areas tend to have a less-permanent resident population than wellestablished owner-occupied housing tracts. In the former areas, residents may be unable or unwilling to participate in the social life of the area. It is important to note that dynamics linking perceived safety to housing tenancy, social cohesion, and ethnicity are intertwined in the case of Jönköping and thus cannot be assessed in isolation, because of the small sample and the way the survey was conducted. The next section touches on the issue of fear of crime as it relates to the housing market in a small town. 


\section{Perceived safety and the housing market in Jönköping}

Most international evidence shows that crime and/or the fear of crime negatively affect the quality of life of residents. As a consequence, housing prices are discounted to compensate for the lack of safety. All other things being equal, buyers are willing to pay more for a house that is located in a safe area. The international literature is populated by examples of the effect of crime on housing prices (Thaler, 1978; Buck, Hakim, \& Spiegel, 1991; Bowes \& Ihlanfeldt, 2001; Lynch \& Rasmussen, 2001; Gibbons, 2004; Tita, Petras, \& Greenbaum, 2006; Munroe, 2007; Troy \& Grove, 2008; Hwang \& Thill, 2009; Ceccato \& Wilhelmsson, 2011, 2012). However, little has been published about the effect of crime and perceived safety on property prices in small towns and rural areas.

Two recent studies in a relatively small housing market but large enough to allow the analysis (Jönköping) assess whether crime and fear of crime impact property prices (Ceccato \& Wilhelmsson, 2014; Wilhelmsson \& Ceccato, 2015). Findings show that residential burglaries decrease house prices but such an effect is slightly more significant for more expensive types of homes than for cheaper ones. The authors also recognize the need to test the potential effect of perceived safety in property prices. They show that low perceived safety decreases property prices after controlling for attributes of the property and neighborhood characteristics, including residential burglary. Also, prices are discounted in areas where people, despite never having been victims of crime, believe that their ethnic background makes them more vulnerable to crime in the neighborhood.

Crime risk may be a driving force of housing security measures such as locks, alarms, security doors, dogs, CCTVs, and many other measures. Studies elsewhere have found that fear of crime led to increased adoption of housing security measures (Hirschfield, Bowers, \& Johnson, 2004), while others have found no relationship (May, Rader, \& Goodrum, 2010). Lewakowski (2012), studying the adoption of household security measures in Stockholm, finds that adoption of measures increases with the perception of crime and altruistic fear but not with victimization. In the case of Jönköping, one-quarter of all respondents had invested in housing security measures, such as safety locks ( 22 percent) and housing alarms (17 percent) in the preceding 12 months, either by themselves or through their homeowners' association. No significant difference was found between groups.

These results mean that, at least in the Swedish context, the mechanisms of buyers' willingness to pay in relatively small housing markets are similar to the ones found in metropolitan areas, evidence that was so far lacking in the international literature. This also means that investing in safety (either on crime-reduction measures or perceived safety) is worthwhile if the goal is to keep prices at current housing market levels, as poor safety is unquestionably a factor that reduces housing prices. This is true even in relatively small municipalities, as was the case here. The analysis does not take into account the rental market and assumes that individuals have the same willingness to pay 
for a commodity, which is not realistic, of course. Housing is a commodity that is not evenly attained, and so is safety, measured either as crime or perceived safety.

\section{Concluding remarks}

This chapter reports on the perception of safety in Sweden focusing on the urban-rural divide and drawing on the theoretical basis discussed in detail in Chapter 6. According to the National Crime Victims survey, there are indications that measures of poor perceived safety have decreased in Sweden since 2006. Regardless of this trend, one group of individuals declares themselves to be more fearful than others. For them, poor perceived safety affects their mobility patterns and quality of life. This group may be composed of those who are more vulnerable to crime in the first place, for a number of reasons, and therefore more fearful. There is no clear urban-rural divide for this group.

As elsewhere in the international literature, fear of victimization in rural Sweden does not only reflect the severity of the crime. Instead, findings show that fear of crime reflects reductions in perceived crime risk, that is, changes in the situational conditions for crime, especially for car-related crime. For example, modern security systems have made it much more difficult to burgle a car, so the fear of becoming a victim of this offense has also dropped. This supports what Warr (2000) once suggested, that the subjective probability of victimization is a proximate cause of fear - not fear itself.

Regardless of this improvement in perceived safety, the trend is not homogeneously distributed geographically or among groups of individuals. In the Swedish case, overall worry seems to encompass more than a declared fear of crime and risk of victimization, as the pattern is quite uniform across the country and shows notable differences between metropolitan and rural areas. This reflects concerns about crime, stability, and social change. One possible explanation for this pattern could be that to a large extent overall fear is fed by fear of crime in large cities, while in rural areas overall fear is mostly determined by concerns about individuals' and households' economic conditions, though both are expressed as "overall worry." Inequality in victimization may also explain this pattern. The poor are victims of crime more often and reveal more anxieties than wealthier groups in Sweden. The poor are overrepresented in some large Swedish cities, such as Stockholm, Malmö, and Gothenburg, which would explain the urban-rural pattern in fear of crime.

Perceived safety varies by group of individual and has an impact on the quality of life of people. Among farmers in Sweden, almost 60 percent feel at least a bit worried about becoming a victim of crime. They tend to be located in the south and have little confidence that, if something happens, they can rely on the police. Although only one-third of farmers have been victims of crime in the past two years, two-thirds know at least one other person who has been victimized. Farmers worry about their properties and about their families. As expected, feeling unsafe is more common for foreign-born individuals than for those who 
were born in Sweden. The same applies to the elderly and ethnic minorities. Alienation, poverty, and poor assistance or protection of human rights is also a fear generator, particularly among the itinerant population. See the case of Sami population and berry pickers. However, there are exceptions. Young women declare, to some extent as elderly women do, a fear of becoming the victim of sexual assault. In the case of Jönköping municipality, the elderly do not feel more worried than the rest of the population, perhaps because they seem to be deeply involved in the local life and social control of their neighborhood.

Crime and fear impact housing markets in small towns and rural areas as they do in urban areas. Again drawing on evidence from Jönköping, crime (residential burglary) and fear of crime had a significant negative effect on housing prices. In the same municipality, "fear of other people" has also shown a direct impact on how attractive an area is valued in the housing market.

Several lessons may be learned from these patterns of perceived safety in Sweden. If crime would cease to exist tomorrow, fear of crime and other anxieties would still be around. This indicates that perceived safety is fed by factors other than perceived risk of victimization. Another lesson is that urbanrural divides in perceived safety (with more people being fearful in urban environments than in rural) represent a rough picture of reality, because there is inequality in both victimization and perceived safety by groups. Some of the factors affecting perceived safety are associated with individual, group, and/or area characteristics. Moreover, some processes triggered by fear seem to have the same impact on people's lives regardless of where they take place. Note the case of the impact of fear on housing prices, for instance.

Another lesson for policy is that it is dangerous to ignore indications of fear. If individuals feel completely safe, they might fail to take the necessary precautions for their own safety, the protection of their property, or the safety of others, and thus increase the risk of victimization. In this case, fear is a positive reaction because it leads to prevention. In another extreme, choosing to boost feelings of fear and other anxieties is an equally poor decision to being taken, as individuals may engage in needless precautions that may be costly without knowing whether there are risks, and if they exist, to know their nature. Individuals' perceived safety may be the tip of the iceberg for a number of triggers that go beyond individual and area-level features. As illustrated in Chapters 6 and 7, perceived safety entails a dimension of reflexivity, which means that it depends on those who observe and produce it, as well as on particular time and space contexts.

What is the role of the police in the reduction of fear in rural areas? The nature and extent of proactive policing measures by police forces in rural communities can help reduce fear. Such measures might include visibility, patrolling, and constant checks. An important question to be answered is safety for whom? As the next few chapters show, neither crime nor perceived safety is the responsibility of a single actor in community policing. Some crime types require efforts of other actors than the police both in crime prevention and/or fear reduction; see Chapters 12 to 14 for examples. 


\section{Notes}

1 The perceived safety variables are derived from the 2013 Safety Survey applied to a stratified sample over urban districts of the municipality of Jönköping. The questionnaire was distributed in spring 2013, with a response rate of 50 percent out of 992 questionnaires (excluding old or incorrect addresses). The questionnaire is composed of 34 questions about victimization, perceived safety in the home, proximity to one's home (neighborhood), and city overall, as well as questions about the respondent's background (e.g., age, gender, income, and education). Respondents were: 57 percent women, 43 percent men; 20 percent primary school education only, 40 percent university degree or equivalent; 28 percent single, 40 percent living in a household with two people; 44 percent rent their home; 22 percent have children at home under 18 years old; 22 percent have household income less than SEK20,000 after taxes, 40 percent SEK21,000-35,000, 28 percent above SEK35,000, and 10 percent did not state their income; 12 percent were born outside the Nordic countries; 51 percent are employed, 3 percent seeking employment, 33 percent retired, 9 percent at home (maternity leave, retired, or seeking employment); 50 percent have lived in the same place more than five years, 80 percent previously lived elsewhere in Jönköping Municipality; 50 percent would be willing to move, but only 2.4 percentage points of those because of insecurity.

2 Söderköping, population approximately 7,000, is $170 \mathrm{~km}$ from Stockholm, half way to Stockholm from Jönköping. The survey team contacted 880 households for telephone interviews in the municipality in 2005 . A total of 300 people were interviewed, 220 in the urban area and 80 in the outer areas of the municipality. The response rate was 38 percent in Söderköping and 27 percent outside the main urban area (see details in Lundin, 2006).

\section{References}

Axelsson, C. (2014). Färre åker till Sverige för att plocka bär. Dagens Nyheter. Retrieved July 3, 2014 from www.dn.se/ekonomi/farre-aker-till-sverige-for-att-plocka-bar/.

Babacan, H. (2012). Racism denial in Australia: The power of silence. Australian Mosaic, $32,1-3$.

Bamzar, R., \& Ceccato, V. (2015). The nature and the geography of elderly injuries in Sweden. GeoJournal, 80(2), 279-299.

Bowes, D. R., \& Ihlanfeldt, K. R. (2001). Identifying the impacts of rail transit stations on residential property values. Journal of Urban Economics, 50(1), 1-25.

Box, S., Hale, C., \& Andrews, G. (1988). Explaining fear of crime. British Journal of Criminology, 28, 340-356.

Brantingham, P., \& Brantingham, P. (1995). Criminality of place: Crime generators and crime attractors. European Journal on Criminal Policy and Research, 3, 1-26.

Brottsförebyggande rådet - BRÅ (National Council of Crime Prevention). (2011). The national victims survey. Stockholm: BRÅ.

Brottsförebyggande rådet - BRÅ (National Council of Crime Prevention). (2014a). Nationella trygghetsundersökningen 2006-2013. Stockholm: BRÅ.

Brottsförebyggande rådet - BRÅ (National Council of Crime Prevention). (2014b). NTU 2013: Om utsatthet, otrygghet och förtroende (p. 172). Stockholm: BRA.

Brottsförebyggande rådet - BRÅ (National Council of Crime Prevention). (2014c). The Swedish Crime Survey 2013: Concerning exposure to crime, insecurity and confidence (p. 12). Stockholm: BRA.

Buck, A. J., Hakim, S., \& Spiegel, U. (1991). Casinos, crime, and real estate values: Do they relate? Journal of Research in Crime and Delinquency, 28(3), 288-303.

Bursik, R. J. (1988). Social disorganisation and theories of crime delinquency: Problems and prospects. Criminology, 26(4), 519-551. 
Bursik, R. J. (1999). The informal control of crime through neighborhood networks. Sociological Focus, 32(1), 85-97.

Cancino, J. M. (2005). The utility of social capital and collective efficacy: Social control policy in nonmetropolitan settings. Criminal Justice Policy Review, 16(3), 287-318.

Carcach, C. (2000). Size, accessibility and crime in regional Australia. Trends and issues in crime and criminal justice (Vol. 175). Canberra: Australian Institute of Criminology.

Ceccato, V. (2013). Moving safely: Crime and perceived safety in Stockholm's subway stations. Plymouth: Lexington.

Ceccato, V., \& Dolmén, L. (2011). Crime in rural Sweden. Applied Geography, 31(1), 119-135.

Ceccato, V., \& Dolmén, L. (2013). Crime prevention in rural Sweden. European Journal of Criminology, 10, 89-112.

Ceccato, V., \& Hanson, M. (2013). Experiences from assessing safety in Vingis Park, Vilnius, Lithuania. Review of European Studies, 5(5), 1-16.

Ceccato, V., \& Wilhelmsson, M. (2011). The impact of crime on apartment prices: Evidence from Stockholm, Sweden. Geografiska Annaler: Series B, Human Geography, 93(1), 81-103.

Ceccato, V., \& Wilhelmsson, M. (2012) Acts of vandalism and fear in neighbourhoods: Do they affect housing prices? In V. Ceccato (Ed.), The urban fabric of crime and fear (pp. 191-212). New York/London: Springer.

Ceccato, V., \& Wilhelmsson, M. (2013). Jönköping safety survey [Database]. Stockholm: CEFIN-KTH.

Ceccato, V., \& Wilhelmsson, M. (2014). The impact of safety on a small town's housing market. Paper presented at the ENHR Conference, Edinburgh.

Chaplin, R., Flatley, J., \& Smith, K. (2011). Crime in England and Wales 2010/11. Home Office Statistical Bulletin. London: Home Office.

Christie, N., Andenaes, J., \& Skirkbeckk, S. (1965). Study of self-reported crime. Scandinavian Studies in Criminology, I, 86-116.

City of Stockholm (2011). Trygg i Stockholm? 2011 En stadsövergripande trygghetsmätning. Stockholm: City of Stockholm, Social care.

Cunneen, C. (2007). Crime, justice and indigenous people. In E. Barclay, J. Donnermeyer, J. Scott, \& R. Hogg (Eds.), Crime in rural Australia (pp. 142-154). Sydney: Federation Press.

Donnermeyer, J., \& Kreps, G. M. (1986). The benefits of crime prevention: A comparative analysis. Columbus, $\mathrm{OH}$ : National Rural Crime Prevention Center.

Eriksson, E., \& Tollefsen, A. (2013). Of berries and seasonal work. In M. Geiger \& A. Pécoud (Eds.), Disciplining the transnational mobility of people (pp. 185-205). Basingstoke: Palgrave Macmillan.

Estrada, F., Nilsson, A., Jerre, K., \& Wikman, S. (2010). Violence at work: The emergence of a social problem. Journal of Scandinavian Studies in Criminology and Crime Prevention, 11(1), 46-65.

Fagerlind, A. L. (2013). Högre krav på bärplockarnas arbetsvillkor. Dagens Nyheter. Retrieved April 11, 2015, from www.dn.se/ekonomi/hogre-krav-pa-barplockarnasarbetsvillkor/.

Forrest, J., \& Dunn, K. (2013). Cultural diversity, racialisation and the experience of racism in rural Australia: The South Australian case. Journal of Rural Studies, 30, 1-9.

Furstenberg, J. F. F. (1971). Public reaction to crime in the streets. American Scholar, 40(40), 601-610. 
Gibbons, S. (2004). The costs of urban property crime. Economic Journal, 114(499), 441-463.

Gray, E., Jackson, J., \& Farrall, S. (2008). Reassessing the fear of crime. European Journal of Criminology, 5(3), 363-380.

Halfacree, K. (2011). Still "Out of place in the country"? Travellers and the postproductivist rural. In R. I. Mawby \& R. Yarwood (Eds.), Rural policing and policing the rural: A constable countryside? (pp. 124-135). Farnham: Ashgate.

Hartshorn, K. J. S., Whitbeck, L. B., \& Hoyt, D. R. (2012). Exploring the relationships of perceived discrimination, anger, and aggression among North American indigenous adolescents. Society and Mental Health, 2(1), 53-67.

Hirschfield, A., Bowers, K. J., \& Johnson, S. D. (2004). Inter-relationships between perceptions of safety, anti-social behaviour and security measures in disadvantaged areas. Security Journal, 17(1), 9-19.

Hofferth, S. L., \& Iceland, J. (1998). Social capital in rural and urban communities 1. Rural Sociology, 63(4), 574-598.

Hollway, W., \& Jefferson, T. (1997). The risk society in an age of anxiety: Situating fear of crime. British Journal of Sociology, 48(2), 255-266.

Hough, M. (1995). Anxiety about crime: Findings from the 1994 British Crime Survey (Vol. 147). London: Home Office, Home Office Research.

Hwang, S., \& Thill, J.-C. (2009). Delineating urban housing submarkets with fuzzy clustering. Environment and Planning B: Planning and Design, 36(5), 865-882.

Jackson, J., \& Gray, E. (2010). Functional fear and public insecurities about crime. British Journal of Criminology, 50(1), 1-21.

Jain, H. C., Singh, P., \& Agocs, C. (2000). Recruitment, selection and promotion of visible-minority and aboriginal police officers in selected Canadian police services. Canadian Public Administration, 43(1), 46-74.

Jansson, L. (2011). Romerna - Det criminella kolletivt: En diskursanalys av svensk medias skildring av romer och kriminalitet (Master's degree, Mid Sweden University, Sundsvall).

Jönköping city office. (2009). Statistiskt faktablad om Jönköping. Jönköping: Jönköping kommun. Retrieved April 12, 2015 from www.jonkoping.se/.

Karlsson, A. (2012). Unga bor i storstan: äldre i glesbygd. Välfärd, 25. Retrieved April 11, 2015, from www.scb.se/sv_/Hitta-statistik/Artiklar/Unga-bor-i-storstan-aldre-iglesbygd.

Lagrange, T. C. (1999). The impact of neighhorhoods, schools, and malls on the spatial distribution of property damage. Journal of Research in Crime and Delinquency, 36(4), 393-422.

Länstyrelsen. (2012). Analys av situationen på bostadsmarknaden 2012. (Vol. 17). Jönköping: Länstyrelsen i Jönköpings län.

Lantbrukarnas Riksförbund (2012). Brott på landet: En undersökning bland lantbrukare. (J. Johansson, Ed., p. 40). Stockholm: Sveriges Lantbruk.

Lawtley, A., \& Deane, M. (2000). Community safety in rural areas. London: NACRO.

Leander, P. (2012). Bärplockare lever i misär i Sverige. Expressen. Retrieved April 11, 2015, from www.expressen.se/nyheter/barplockare-lever-i-misar-i-sverige/.

Lewakowski, B. (2012). Half locked? Assessing the distribution of household safety protection in Stockholm (Master's thesis, Royal Institute of Technology, Stockholm).

Lewis, D. A., \& Maxfield, M. G. (1980). Fear in the neighborhoods: An investigation of the impact of crime. Journal of Research in Crime and Delinquency, 17(2), $160-189$. 


\section{2}

Lundin, T. (2006). Safety survey in Söderköping (p. 53). Söderköping: Söderköpings kommun.

Lynch, A. K., \& Rasmussen, D. W. (2001). Measuring the impact of crime on house prices. Applied Economics, 33(15), 1981-1989.

Marshall, B., \& Johnson, S. (2005). Crime in rural areas: A review of the literature for the rural evidence research centre. Jill Dando Institute of Crime Science, University College, London.

May, D. C., Rader, N. E., \& Goodrum, S. (2010). A gendered assessment of the "threat of victimization": Examining gender differences in fear of crime, perceived risk, avoidance, and defensive behaviors. Criminal Justice Review, 35(2), 159-182.

Milgram, S. (1974). The experience of living in cities. In C. M. Loo (Ed.), Crowding and behavior (pp. 41-54). New York: MSS Information Cooperation

Munroe, E. D. K. (2007). Exploring the determinants of spatial pattern in residential land markets: Amenities and disamenities in Charlotte, NC, USA. Environment and Planning B: Planning and Design, 34(2), 336-354.

Omma, L. (2013). Ung same i Sverige: Livsvillkor, självvärdering och hälsa. Umeå: Umeå University.

Pain, R. (2000). Place, social relations and the fear of crime: A review. Progress in Human Geography, 24(3), 365-387.

Pred, A. (2000). Even in Sweden: Racisms, racialized spaces, and the popular geographical imagination. Berkeley, LA/London: University of California Press.

Sacco, V. (2005). When crime waves. London: Sage.

Sampson, R. J., Raudenbush, S. W., \& Earls, F. (1997). Neighborhoods and violent crime: A multilevel study of collective efficacy. Science, 277(5328), 918-924.

Sandercock, R. J. (Ed.). (2005). Difference, fear and habitus: A political economy of urban fear. Aldershot: Ashgate.

Schyllander, J., \& Rosenberg, T. (2010). Skador bland äldre i Sverige. Stockholm: Myndigheten för samhällsskydd och beredskap (MSB). Retrieved April 12, 2015, from www.msb.se/RibData/Filer/pdf/25570.pdf.

Scott, J., Carrington, K., \& McIntosh, A. (2012). Established-outsider relations and fear of crime in mining towns. Sociologia Ruralis, 52(2), 147-169.

Skielta, A. (2014). Sapmi. Retrieved July, 7, 2014, from www.samer.se.

Skogan, W. G. (1990). Disorder and decline: Crime and the spiral of decay in American neighborhoods. New York: Free Press.

Thaler, R. (1978). A note on the value of crime control: Evidence from the property market. Journal of Urban Economics, 5(1), 137-145.

Tita, G., Petras, T., \& Greenbaum, R. (2006). Crime and residential choice: A neighborhood level analysis of the impact of crime on housing prices. Journal of Quantitative Criminology, 22(4), 299-317.

Torstensson, G., Forslund, M., \& Tegnell, A. (2011). Förslag till nationell handlingsplan för säkerhetsfrämjande arbete för äldre personer (Vol. 12, p. 48). Stockholm: Socialstyrelsen.

Troy, A., \& Grove, J. M. (2008). Property values, parks, and crime: A hedonic analysis in Baltimore, MD. Landscape and Urban Planning, 87(3), 233-245.

Urry, J. (2002). Mobility and proximity. Sociology, 36(2), 255-274.

Warr, M. (2000). Fear of crime in the United States: Avenues for research and policy. Criminal Justice and Behavior, 4, 451-489.

Wilhelmsson, M., \& Ceccato, V. (2015). Challenging the idyll: Does crime affect property prices in Swedish rural areas? Journal of Rural Studies, 39 (in press).

Wilson, J. Q., \& Kelling, G. L. (1982). Broken windows. Atlantic Monthly, 249, 29-38. 